IRA-International Journal of Education \&

Multidisciplinary Studies

ISSN 2455-2526; Vol.15, Issue 03 (June 2019)

Pg. no. 100-103.

Institute of Research Advances

http://research-advances.org/index.php/IJEMS

\title{
Alternate Skilling and its Relevance for the Freelancing Choices for College Graduates: An Interpretation
}

\author{
Pooja M. \\ Educational Writing Coach \\ Member, The Institute of Company Secretaries of India, New Delhi, India.
}

Type of Work: Peer Reviewed

DOl: http://dx.doi.org/10.21013/jems.v15.n3.p2

\section{How to cite this paper:}

Pooja, M. (2019). Alternate Skilling and its Relevance for the Freelancing Choices for College Graduates: An Interpretation. IRA International Journal of Education and Multidisciplinary Studies (ISSN 2455-2526), 15(3), 100-103.doi: http://dx.doi.org/10.21013/jems.v15.n3.p2

(c) Institute of Research Advances.

This work is licensed under a Creative Commons Attribution-Non Commercial 4.0 International License subject to a proper citation to the publication source of the work.

Disclaimer: The scholarly papers as reviewed and published by the Institute of Research Advances (IRA) are the views and opinions of their respective authors and are not the views or opinions of the IRA. The IRA disclaims of any harm or loss caused due to the published content to any party.

Institute of Research Advances is an institutional publisher member of Publishers International Linking Association Inc. (PILA-CrossRef), USA. The institute is an institutional signatory to the Budapest Open Access Initiative, Hungary advocating the open access of scientific and scholarly knowledge. The Institute is a registered content provider under Open Access Initiative Protocol for Metadata Harvesting (OAI-PMH).

The journal is indexed \& included in WorldCat Discovery Service (USA), CrossRef Metadata Search (USA), WorldCat (USA), OCLC (USA), Open J-Gate (India), EZB (Germany) Scilit (Switzerland), Airiti (China), Bielefeld Academic Search Engine (BASE) of Bielefeld University, Germany, PKP Index of Simon Fraser University, Canada. 


\begin{abstract}
Traditional higher education has been witnessing vast changes and trends are showing up that student across countries and courses have taken up the alternate skilling as career security. The students are not just studying their regular courseware but they are also exploring the skills which can make them more employable and attractive for the future job market. One of the alternate results of this alternate skilling has been as the freelancing work culture among fresh college graduates or its adoption by the regular workforce. This article interprets the relevance of the alternate skilling for the freelancing choices of college students.
\end{abstract}

Keywords: Alternate Skills, Freelancing, Jobs Choices, Higher Education

\begin{abstract}
Alternate Skilling
When a student attains or aspires to attain a certain job or employment-oriented skill besides and different from his regular courseware, this is known as alternate skilling. Alternate skilling for those who are already working in some job or the other is when they start acquiring or learn to acquire a new skill entirely different from the skills they are having or the jobs they are doing.
\end{abstract}

\title{
How Alternate Skilling Create Freelancing Aspirations among College Student
}

Job security, increased educational loans and employment trends are some of the key issues which make the students explore different skills to ensure a work opportunity for them.

\section{Sense of Doing Something Independently}

When students find that they can work on their own after attaining certain skill, they prefer to freelance. The generation $\mathrm{X}$ is increasingly orienting itself towards freelancing and the generation $\mathrm{Z}$ will majorly be inclined to be their own bosses.

\section{Practical Hard Skills versus Theoretical Knowledge}

When students skill them via alternate skilling, they are more confident to take first move in comparison to those who first learn theory. Practical know-how increases the confidence level among students to take up independent work opportunities or freelancing assignments.

\section{Future Estimates}

As per a study by Upwork ${ }^{1}$, a freelancing platform, by 2017, the majority of the US workforce will work as a freelancer. The study estimates the freelancing workforce to be over 86.5 million as compared to the non-freelancing workforce of 83.4 million.

Different studies estimate positive outlooks for the freelancing trends across job verticals. All this makes alternate skilling more acceptable to the college student as a token of job/work security.

\section{Broken Education Systems across Nations}

The contemporary education system is way behind to make college students worth to be hired. The industry preferred skills aren't part of the existing curriculum. There is a breakage between the degrees and the skills. This broken education system is further making alternate skilling a preferred medium of attaining job-ready skills.

\footnotetext{
${ }^{1}$ Source: https://www.upwork.com/i/freelancing-in-america/2017/
} 


\section{Alternate Skilling \& Freelancing Choices}

\begin{tabular}{|c|c|c|}
\hline $\begin{array}{c}\text { Surveyed Subjects (in } \\
\text { numbers) }\end{array}$ & $\begin{array}{c}\text { Whether aware of alternate } \\
\text { skilling }\end{array}$ & $\begin{array}{c}\text { If yes, whether they prefer to } \\
\text { freelance }\end{array}$ \\
\hline 58 College-Goers & $42(\mathrm{Y})$ & $34(\mathrm{Y}) / 42$ \\
\hline 30 College Graduates & $30(\mathrm{Y})$ & $18(\mathrm{Y}) / 30$ \\
\hline
\end{tabular}

Source: Primary

Y: Yes

The above survey results were obtained by the author via a Facebook survey campaign. The responses were collected over a period of a week. The respondents were from 12 countries. The survey found that more than $72 \%$ college students were aware of the alternate skilling. Nearly $81 \%$ of these prefer to freelance. On the other hand, all of the surveyed college graduates knew about the alternate skilling. $60 \%$ of the college students were inclined to freelance as compared to college-goers who stood at $81 \%$ to freelance.

The survey findings show that more college students prefer to work as freelancers when they acquire a certain skill via alternate skilling.

\section{Limitation of the Survey}

The survey size though covering 12 countries but the survey subjects were small in numbers. Future studies may embark on larger survey size to materialize more conclusions.

\section{What Makes Freelancing More Lucrative to College Students?}

Freelancing has gained popularity in recent years, especially in Asian countries where educated unemployment is more and this industry is growing rapidly. Recent studies say that freelancers are working more than 1 billion hours per week. People find it easy to provide freelance services due to no job opportunities in the market, long working hours, no optimum incentives and long hours of travel time. The younger generation has made it their choice to work as freelancers due to higher earnings and flexible timings and more than 60 per cent of people fall into this category according to a recent study.

Females find it easy to work from home so that they can look after their families and work conveniently. About $84 \%$ full time freelance workers are enjoying their life as freelancers and says they are living their lives in a way they have desired of whereas this percentage are only 63 in case of traditional work culture and 64 per cent freelancers feel them healthier than traditional workers because of not continuously sitting at desk, less stress, no long hours of travelling and are able to spend more time with family. People are moving from traditional job culture to freelancing because of compromising work culture, targets and deadlines and inadequate incentives from the employers.

College graduates are more in this field due to the lack of opportunities to work in big companies. They spend many years and hundreds of dollars for their degrees and when they apply for a job and do not get the response they feel depressed. Debts and stress keep on increasing and time goes on. Parents' expectations increases and self-confidence tends to decrease. Frustration and wait for the call from a big company let them enter into freelancing.

America has 53 million freelancers and by 2020 , every one out of two will be providing freelancing work and this is the need of the new digitized economy in which you can work anytime from anywhere independently. You can spend more time with nears and dears without asking for leave from the employer 
and without compromising with the work. You get payments for your work done on time and have extra time to devote to the personal sides.

No doubt, freelancing jobs are getting popular day by day but power cuts, uninterrupted broadband and internet connections, lack of payment receiving options and traditional work culture are some of the challenges which still exist in developing countries. Health insurance is also a concern for freelance workers wherein the cost of premiums has increased significantly and freelancer has to bear this entire cost from their own pockets.

Almost 50 per cent of freelancers are uninsured and they have not taken any health insurance plans yet because of rising premiums. In traditional work culture, this cost is borne by the employer or provided to the employee in the form of allowances.

According to the Oxford Internet Institute ${ }^{2}$, India, Bangladesh and US are providing $24 \%, 16 \%$ and $12 \%$ of total global online labour respectively in technology, software and marketing support sector but this is not enough because lots of sectors are still untouched by freelance workers because of not proper highlights of this field.

The government should take initiative and come forward with a planned programme to convert unemployed educated people into freelancers by providing support, initiatives and credibility to make their country digitized by providing tech-savvy labour.

\section{What Lies Ahead?}

The freelancers equipped with the industry preferred skills will be seen as an asset by both the freelancers as well as the society. The companies will be able to outsource certain work attaining high performance at the same minimizing their operational costs. The social benefits of freelancing i.e. more balance social life and many other positives will highly be regarded as social fruit. The academia, governments and employers will all be looked upon as the force behind making the freelancing more attractive, balancing and result-oriented work culture.

\section{References:}

[1]. Brown, R. (2005). Performing arts creative enterprise: Approaches to promoting entrepreneurship in arts higher education. The International Journal of Entrepreneurship and Innovation, 6(3), 159-167.

[2]. Comunian, R., Gilmore, A., \& Jacobi, S. (2015). Higher education and the creative economy: creative graduates, knowledge transfer and regional impact debates. Geography Compass, 9(7), 371-383.

[3]. Grimov, O. (2016). Main features of freelancing as a non-standard form of employment. Економічний часопис-XXI, 157(3-4 (1)), 79-81.

[4]. Matlay, H., \& Rae, D. (2007). Connecting enterprise and graduate employability. Education+ Training.

[5]. Osnowitz, D. (2010). Freelancing expertise: Contract professionals in the new economy. Cornell University Press.

\footnotetext{
${ }^{2}$ Report available at : https://www.oii.ox.ac.uk/publications/platform-sourcing.pdf
} 